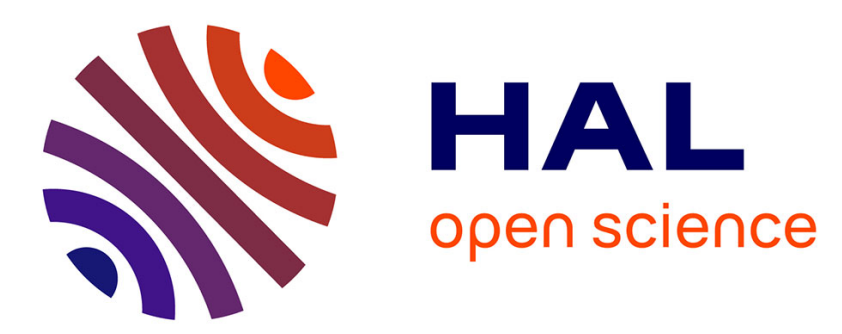

\title{
Interspecific and geographical variations of trace element concentrations in Pectinidae from European waters
}

\author{
Paco Bustamante, Pierre Miramand
}

\section{To cite this version:}

Paco Bustamante, Pierre Miramand. Interspecific and geographical variations of trace element concentrations in Pectinidae from European waters. Chemosphere, 2004, 57 (10), pp.1355-1362. 10.1016/j.chemosphere.2004.08.077 . hal-00186644

\section{HAL Id: hal-00186644 https://hal.science/hal-00186644}

Submitted on 10 Nov 2007

HAL is a multi-disciplinary open access archive for the deposit and dissemination of scientific research documents, whether they are published or not. The documents may come from teaching and research institutions in France or abroad, or from public or private research centers.
L'archive ouverte pluridisciplinaire HAL, est destinée au dépôt et à la diffusion de documents scientifiques de niveau recherche, publiés ou non, émanant des établissements d'enseignement et de recherche français ou étrangers, des laboratoires publics ou privés. 
1 Interspecific and geographical variations of trace

2 element concentrations in Pectinidae from European

3 Waters

4

$5 \quad$ Paco Bustamante*, Pierre Miramand

6

7 Laboratoire de Biologie et Environnement Marins, FRE 2727 du CNRS, Université de La

8 Rochelle, 22, Avenue Michel Crépeau, F-17042 La Rochelle, France

9

10 *Corresponding author: Dr. Paco Bustamante

11 Laboratoire de Biologie et Environnement Marins,

12 FRE 2727 du CNRS

13 Université de La Rochelle

14 22, Avenue Michel Crépeau

15 F-17042 La Rochelle (France)

16

17

* Corresponding author. Tel.:+33 546500 294; e-mail: pbustama@univ-lr.fr 
24 ABSTRACT : $\mathrm{Cd}, \mathrm{Cu}$ and $\mathrm{Zn}$ were analysed in the organs and tissues of the three scallop species from the Bay of Biscay, the variegated Chlamys varia L., the queen scallop Aequipecten opercularis L. and the common scallop Pecten maximus L. for interspecific comparisons. In P. maximus the greatest concentrations of $\mathrm{Cd}$ and $\mathrm{Cu}$ were found in the digestive gland, whereas the two other species showed similar levels of $\mathrm{Cd}$ between digestive gland and kidneys and higher renal $\mathrm{Cu}$ concentrations. However, the digestive gland of all Pectinidae species contained from 75 to $93 \%$ and 52 to $74 \%$ of the total body burdens of $\mathrm{Cd}$ and $\mathrm{Cu}$, respectively. Whatever the species and the origin, kidneys displayed the highest $\mathrm{Zn}$ concentrations, which therefore contained from 53 to 97 $\%$ of the total body burden of this metal. Also using reported results, ratios between the concentrations in the digestive gland and that in the kidneys discriminated two groups of Pectinidae : 1) the Pecten group (P. maximus, P. jacobeus and Adamussium colbecki) with a $\mathrm{Cd}$ ratio $\geq 4$, a $\mathrm{Cu}$ ratio $\geq 1$ and a $\mathrm{Zn}$ ratio $>20.10^{-3} 2$ ) the Chlamys group with a $\mathrm{Cd}$ ratio $\leq 1$, a $\mathrm{Cu}$ ratio $\leq 1$ and a $\mathrm{Zn}$ ratio $\leq 6 \cdot 10^{-3}$. However, no differences in the detoxification processes in the digestive gland were found between groups in this study. 72 to $80 \%$ of the total $\mathrm{Cd}$ was found to be soluble, probably bound to metalloproteins such as metallothioneins, while $\mathrm{Cu}$ and $\mathrm{Zn}$ were mainly found associated to the insoluble fraction of the digestive gland cells whatever the species. Queen scallops from the Faroe Islands were also considered to examine variations of the metal concentrations due to the geographical origin. In this northern area, queen scallops displayed Cd concentrations 2, 4 and 6 times higher in kidneys, muscle and digestive gland, respectively, compared to those from the Bay of Biscay. Consequently, the $\mathrm{Cd}$ concentrations in the whole soft parts of the queen scallops were more than 6 times higher in the Faroe Islands than in the 
47 Bay of Biscay. In contrast to $\mathrm{Cd}$, both $\mathrm{Cu}$ and $\mathrm{Zn}$ concentrations in the whole soft parts were 2 times lower in the Faroe Islands, suggesting lower bioavailability of these essential elements.

Key words: Heavy metals ; Bioaccumulation ; Body distribution ; Subcellular distribution ; Scallop

\section{INTRODUCTION}

Among seashells, numerous scallop species represent an important target to commercial fisheries. Many of them are actually cultured for direct commercial production or to provide juveniles for reintroduction programs in areas over-exploited. On the French Atlantic coasts and in the English Channel, scallops are relatively common, largely distributed and belong to three species: the variegated scallop Chlamys varia on rocky substrata, the queen scallop Aequipecten opercularis and the common scallop Pecten maximus on sandy bottoms. In France, these three species are captured during winter time and mobilises around one thousand fishing boats with various duration. The total of the catch varies greatly form one year to another, ranging from 6000 tons to 25000 tons per year (Quéro and Vayne, 1998). The three species are also captured for leisure activities, directly on the shore or by snorkelling. Scallops represent therefore an elevated economic values in fishing areas. 
69 Bivalves are classically chosen for studies on trace element bioaccumulation (Bryan

70 1976). They are poorly capable to regulate ion concentrations in internal fluids and they

71 are highly tolerant, metal ions being sequestered in excess of metabolic requirement

72 (George, 1980). Therefore, bivalves often display high accumulation levels without

73 apparent toxic effect. Among bivalves, scallops have shown a particular ability to

74 concentrate high levels of pollutants such as trace elements, even in areas remote from

75 direct anthropogenic contamination like the Antarctic (Mauri et al., 1990, Berkman and

76 Nigro, 1992, Viarengo et al., 1993) or the Arctic Oceans (Stepnowski and Skwarzec,

77 2000). Therefore, scallops are generally considered as valuable bioindicators to monitor

78 marine pollution (Bryan, 1973, Bustamante et al., 2002a). However, large interspecific

79 variations seem to occur when compared trace element concentrations between different

80 scallop species (Mauri et al., 1990, Viarengo et al., 1993). Such variations are not well

81 characterized since only a single species is usually studied at the same place.

82 Furthermore, geographical variations for a single scallop species have been rarely

83 considered, different species from various latitudes being generally compared.

84

85 In this study, $\mathrm{Cd}, \mathrm{Cu}$ and $\mathrm{Zn}$, were analyzed in the organs and tissues of the three 86 common scallop species living along the Atlantic coast of France. Those metals were

87 determined by flame and graphite atomic absorption spectrophotometry in the variegated

88 scallop $C$. varia, in the queen scallop $A$. opercularis and in the common scallop $P$.

89 maximus, from the Charente-Maritime coasts, Bay of Biscay, France, in an attempt to

90 determine the interspecific variations in the metal bioaccumulation. Furthermore,

91 specimens of $A$. opercularis, a widely distributed species in the Northeastern Atlantic 
92 from Morocco to the north of Norway, were collected off the Faroe Islands for

$109 \quad(n=31)$.

110 For each scallop, adductor muscle, gonad, gills, kidneys, and digestive gland were

111 separated from the rest of the soft part. The remaining tissues including the mantle, the 112 foot, the intestine and the heart, were also analysed in order to calculate the whole trace 113 element contained of the soft parts.

\section{MATERIAL AND METHODS}

\section{Sampling and sample preparation}

In February 1996, 41 variegated scallops (Chlamys varia, Linné, 1758) were collected by hand in the infralittoral zone in the coast of Charente-Maritime (Bay of Biscay, France). After 48 hours depuration in clean sea water to eliminate faecal and pseudo-faecal material, scallops were pooled by size classes.

The queen and common scallops (Aequipecten opercularis, Linné, 1758 and Pecten maximus, Linné, 1758, respectively) have been opportunistically collected by bottom trawl along the Charente-Maritime coasts between February and May 1997. Individuals ( $\mathrm{n}=11$ for each species) were separated in individual plastic bags and frozen on board.

Queen scallops A. opercularis from the Faroe Islands have also been collected opportunistically by bottom trawl in August 1996 and frozen on board as described above 
116 The partitioning of trace elements between soluble and insoluble subcellular fractions of

117 the digestive gland was investigated in the three scallop species. Thus, 40 Chlamys varia,

11823 Pecten maximus, and 10 Aequipecten opercularis were devoted to subcellular

119 investigations. Four pools were made with the digestive glands removed from the soft

120 parts of $C$. varia and $P$. Maximus freshly dissected. In the case of A. opercularis,

121 digestive glands were removed on board to be deep frozen in liquid nitrogen and

122 consequently were treated individually.

123 Both pooled and individual digestive glands were subsequently homogenised in a Dounce 124 potter on ice with 10 volumes of a $0.02 \mathrm{M}$ TRIS-HCl buffer in $0.25 \mathrm{M}$ sucrose with 1 $125 \mathrm{mM}$ PMSF (phenylmethylsulfonylfluoride, as protease inhibitor) and $5 \mathrm{mM}$ DTT 126 (dithiothreitol, as reducing agent), at pH 8.6 (Bustamante et al. 2002b). The homogenates 127 were centrifuged at $100000 \mathrm{G}$ for $1 \mathrm{~h}$ at $4^{\circ} \mathrm{C}$ in a Beckman LE-70 ultracentrifuge. 128 Particle-free supernatants (cytosols) were separated from the pellet. Aliquots of the 129 homogenates, cytosols and pellets were analysed for trace elements.

\section{$131 \quad$ Trace element analyses}

132 Tissue samples were dried for several days at $80^{\circ} \mathrm{C}$ to constant weight. Whenever 133 possible, two aliquots of approx. $300 \mathrm{mg}$ of each homogenised dry sample were digested 134 with $4 \mathrm{ml}$ of $65 \%$ ultrapure $\mathrm{HNO}_{3}$ and $0.3 \mathrm{ml}$ of ultrapure $70 \% \mathrm{HClO}_{4}$ at $80^{\circ} \mathrm{C}$ until the 135 solution was clear. Then acids were evaporated and residues were dissolved in $0.3 \mathrm{~N}$ 136 ultrapure nitric acid. 
137 Cadmium, copper and zinc were determined by flame and graphite furnace atomic

138 absorption spectrophotometry with a Varian spectrophotometer Vectra 250 Plus, with

139 Deuterium background correction. Certified reference materials, dogfish liver DOLT-2

140 (NRCC) and dogfish muscle DORM-2 (NRCC), were treated and analysed in the same

141 way as the samples. The results for standard reference materials were in good agreement

142 with certified values (Table 1). The detection limits calculated for $0.3 \mathrm{~g}$ of dry tissue were

$143\left(\mu \mathrm{g} \cdot \mathrm{g}^{-1} \mathrm{dwt}\right): 0.005(\mathrm{Cd}), 0.5(\mathrm{Cu})$, and $3(\mathrm{Zn})$. Metal concentrations in tissues are given

144 relatively to the dry weight $\left(\mu \mathrm{g} \cdot \mathrm{g}^{-1}\right.$ dry wt) while the distribution percentages were

145 calculated for wet weight.

147 Data analyses

148 Comparison of metal concentrations between species were tested by one-way ANOVA 149 (after $\log$ transformation of data when necessary) followed by the Tukey's multiple 150 comparison test in the MINITAB 13.1 software. Changes in metal distribution among 151 scallop tissues were tested for significance by the $G$ procedure (adapted from the log152 likelihood ratio test) for $2 \times \mathrm{k}$ contingency tables (Zar, 1996). The significance level for 153 statistical analyses was always set at $\alpha=0.05$.

\section{RESULTS}

157 Concentrations of $\mathrm{Cd}, \mathrm{Cu}$ and $\mathrm{Zn}$ in the tissues of 3 scallop species from the Bay of 158 Biscay and 1 species from the Faroe Islands are presented in Table 2. Concentrations in 159 the whole soft parts were calculated using the concentrations determined in each 
compartments. The body distribution of the trace elements of the scallops is presented in

161 Table 3.

\section{Cadmium}

Among tissues, the digestive gland and the kidneys displayed the highest $\mathrm{Cd}$ concentrations for all species and in both areas. Interestingly, the $\mathrm{Cd}$ values measured in the different species were in the same range of concentrations in both organs with the

167 exception of P. maximus. In this species, $\mathrm{Cd}$ concentrations in this species were around 4 168 times higher in the digestive gland than in the kidneys, i.e. $264 \pm 33 \mu \mathrm{g} . \mathrm{g}^{-1} \mathrm{dwt} v s 70.6 \pm$ $16912.6 \mu \mathrm{g} \cdot \mathrm{g}^{-1} \mathrm{dwt}$, respectively (Table 2). The digestive gland contained most of the total 170 body burden of $\mathrm{Cd}$ in all species, probably because of the significance in weight of this 171 organ (Table 3). For Cd, a G-test did not indicate any significant ( $>0.05)$ difference 172 among metal body distribution between species and areas.

173 Among the scallops from the Bay of Biscay, P. maximus showed a strong accumulation 174 of $\mathrm{Cd}$ in its tissues, especially in kidneys, muscle and digestive gland compared to the 175 other species. Thus, these tissues displayed Cd concentrations 2, 4, and 6 times higher, 176 respectively, than those measured in C. varia and in A. opercularis (Table 2). 177 Consequently, the whole soft parts of $P$. maximus contained Cd concentrations more than 1784 times higher than in the other two scallop species (Table 2).

179 When compared Faroe Islands and Bay of Biscay, Cd concentrations in A. opercularis 180 were in the same range in the gonad, gills, and muscles for both geographic areas $(\mathrm{F}=2.31$ $181 \mathrm{p}=0.140$ ). Nevertheless, A. opercularis from the Faroe Islands displayed more than 4 182 times Cd concentrations in the digestive gland and 7 times higher in the kidneys than in 
queen scallops from the Bay of Biscay (Table 2). Consequently, the digestive gland of $A$. opercularis from the Faroe Island contained even higher percentage to the total body burdens of $\mathrm{Cd}$, i.e. $90 \%$ vs $75 \%$ (Table 3). Whichever the origin was, in the digestive gland of the three species more than $70 \%$ of the total $\mathrm{Cd}$ was found in the particle free supernatants (Table 4).

\section{Copper}

Similarly to $\mathrm{Cd}$, the digestive gland and the kidneys displayed the highest $\mathrm{Cu}$ concentrations for all species and in both areas. However, this metal displayed large variations according to the species and to the origin of the scallop.

In the scallops from the Bay of Biscay, $\mathrm{Cu}$ clearly showed the highest concentrations in kidneys except for $P$. maximus, whose concentrations were 3 times higher in the digestive gland (Table 2). Specifically in this species, the gonad exhibited relatively elevated $\mathrm{Cu}$ concentrations $\left(19.7 \pm 16.1 \mu \mathrm{g} \cdot \mathrm{g}^{-1} \mathrm{dwt}\right)$, which were in the same order of magnitude than in kidneys $\left(13.5 \pm 2.0 \mu \mathrm{g} \cdot \mathrm{g}^{-1} \mathrm{dwt}\right)$. Despite such variations in the $\mathrm{Cu}$ concentrations, the digestive gland of the different scallop species contained most of the whole body burden of $\mathrm{Cu}$ (Table 3). Therefore, tissue distribution of $\mathrm{Cu}$ did not varied significantly (G-test, $\mathrm{p}>0.05)$ between all the different scallop species.

Considering the whole soft parts, scallops from the Faroe Islands showed $\mathrm{Cu}$ concentrations 2 times lower than those from the Bay of Biscay (Table 2). Globally, the concentrations of $\mathrm{Cu}$ in the gonad, gills, muscle and remaining tissues were slightly lower in scallop from the Faroe Islands. This difference was even more important for the digestive gland and kidneys (Table 2). However, the digestive gland of the scallops from 
206 the Faroe Islands also contained most of the whole body burden of $\mathrm{Cu}$, i.e. $61 \pm 4 \%$

207 (Table 3).

208 Whichever the origin was, in the digestive gland most of the $\mathrm{Cu}$ was found associated to

209 the pellet of centrifugation, only 25 to $43 \%$ of the total $\mathrm{Cu}$ being soluble (Table 4 ).

211 Zinc

212 In scallops, kidneys displayed the highest $\mathrm{Zn}$ concentrations for all species and in both

213 areas(Table 2). These concentrations were several thousand of $\mu \mathrm{g}$ (i.e. exceeding 30,000

$214 \mu \mathrm{g} \mathrm{Zn.g^{-1 }}$ in A. opercularis from the Bay of Biscay).

215 In the Bay of Biscay, the concentrations of $\mathrm{Zn}$ were 7 times higher in A. opercularis than

216 in $P$. maximus but not significantly different from $C$. varia. In contrast, $P$. maximus

217 exhibited $\mathrm{Zn}$ concentrations in the digestive gland which were 4 times higher than in $C$.

218 varia and A. opercularis. Despite such differences in the tissue concentrations, kidneys of

219 the different scallop species contained from 72 to $91 \%$ of the whole body burden of $\mathrm{Zn}$

220 (Table 3). Moreover, a G-test did not indicate any significant ( $p>0.05)$ difference among

221 metal body distribution between these species.

222 In the Faroe Islands, A. opercularis exhibited lower Zn concentrations in all their tissues

223 than in the Bay of Biscay (Table 2). This was particularly obvious for the kidneys which

224 concentrations were 7 times lower compared to A. opercularis from the Bay of Biscay

225 while such a difference was only a 2 or 3 fold for the other tissues. Consequently, $A$.

226 opercularis from the Faroe Islands only exhibited $53 \%$ of the whole body burden of $\mathrm{Zn}$

227 in their kidneys (Table 3). 
Despite interspecific and geographical differences in the concentrations, the proportion of soluble $\mathrm{Zn}$ within the digestive gland cells poorly varied, i.e. from 38 to $50 \%$ in the different scallop species (Table 4).

\section{DISCUSSION}

\section{Interspecific comparisons}

Among bivalves, scallops accumulate trace elements at often high concentrations, depending on the metal and the tissue. The kidney and the digestive gland have a major importance in the bioaccumulation of $\mathrm{Cd}, \mathrm{Cu}$ and $\mathrm{Zn}$ in Pectinidae. These organs exhibited high metal concentrations and contained most of the total body burden of these trace elements (Tables $1 \& 2$ ). The other tissues seems to have a minor importance in the storage of $\mathrm{Cd}, \mathrm{Cu}$ and $\mathrm{Zn}$ although they might have a major role in uptake and transfer of trace elements. However, one of the goals of the present study was to provide background levels against which to perform interspecific comparison within the Pectinidae family. Results from this study allowed to discriminate two groups of scallops : on the one hand Chlamys varia and Aequipecten opercularis (formerly called Chlamys opercularis) and on the other side Pecten maximus. These two groups are revealed by the ratio between the concentrations of trace elements in the digestive gland and that in kidneys : 1) the Pecten group ( $P$. maximus) with a $\mathrm{Cd}$ ratio $\geq 4$, a $\mathrm{Cu}$ ratio $\geq 1$ and a $\mathrm{Zn}$ ratio $>20.10^{-3}$ and, 2 ) the Chlamys group (C. varia and A. opercularis) with a $\mathrm{Cd}$ ratio $\leq 1$, a $\mathrm{Cu}$ ratio $\leq 1$ and a $\mathrm{Zn}$ ratio $\leq 6.10^{-3}$. Even though metal concentrations have been studied in various scallop species, little data from the current literature allowed to make such calculations, mainly 
because of the lack of values in kidneys. Table 5 reports $\mathrm{Cd}, \mathrm{Cu}$ and $\mathrm{Zn}$ concentrations in

252 the digestive gland and kidneys of different scallops species from various locations. Even

253 though the variation of the concentrations of $\mathrm{Cd}, \mathrm{Cu}$ and $\mathrm{Zn}$ in both tissues is very large,

254 the ratio of the concentrations between the digestive gland and the kidneys were

255 consistent with our results. Thus, $P$. maximus from the English Channel and P. jacobeus

256 from the Mediterranean showed ratios around 4 for $\mathrm{Cd},>20.10^{-3}$ for $\mathrm{Zn}$, and respectively

2573 and 1 for $\mathrm{Cu}$. These calculated ratio were even higher for the Antarctic scallop

258 Adamussium colbecki (i.e. 12 for $\mathrm{Cd}, 3$ for $\mathrm{Cu}$ and $377.10^{-3}$ for $\mathrm{Zn}$ ) suggesting a

259 metabolism of metals close to the one of the Pecten group. In contrast, taking into

260 account the moisture of the tissues, a ratio around 1 for $\mathrm{Cd}$ suggests that Placopecten

261 magellanicus is closer to the Chlamys group.

262 The bioaccumulation of trace elements in the digestive gland and kidneys might be

263 related to the detoxification processes of metals. The reasons of high concentrations of

264 trace elements in the tissues of Pectinidae are typically attributed to the binding to

265 cytosolic proteins in the digestive gland and to precipitation on granules in kidneys

266 (George et al., 1980, Ballan-Dufrançais et al., 1985, Stone et al., 1986, Fowler and Gould,

267 1988, Mauri et al., 1990, Viarengo et al., 1993). Globally, information on the subcellular

268 distribution of metals in Pectinidae is scarce. The cytosolic proteins of the digestive gland

269 cells of the three scallop species seem to have a minor importance in the binding of $\mathrm{Cu}$

270 and $\mathrm{Zn}$. These two metals were generally found in large proportions into the insoluble

271 fraction, which represent the metals trapped within the organites, associated to

272 membranes or to granules. This might be due to their numerous biochemical functions

273 that imply they are involved in the structure of several proteins. In contrast to $\mathrm{Cu}$ and $\mathrm{Zn}$, 

from 72 to $80 \%$ of the total Cd was found in the cytosolic fraction of the digestive gland cells of the three scallop species. With the exception of the Antarctic scallop Adamussium colbecki, for which only $30 \%$ of the total Cd was soluble (Viarengo et al., 1993), 60 to $99 \%$ of the Cd was found in the soluble fraction of the digestive gland of Pectinidae from field or after experimental exposure to this metal (Evtushenko et al., 1986, 1990, Stone et al., 1986, Lukyanova and Evtushenko, 1989). This strongly suggests the occurrence of mechanisms of accumulation and detoxification of $\mathrm{Cd}$ involving proteins

281 such as metallothioneins (Evtushenko et al., 1986, 1990, Stone et al., 1986, Viarengo et 282 al., 1993, Bustamante, 1998). Similar detoxification strategies for $\mathrm{Cd}, \mathrm{Cu}$ and $\mathrm{Zn}$ in the 283 digestive gland of the Chlamys and the Pecten groups suggest that differences between 284 the two groups are related to detoxification and excretion processes in the kidneys. 285 Indeed, metal-rich granules from the kidney of P. maximus are considered as excretory 286 concretions which can be eliminated in urine (George et al., 1980). Higher excretion rates 287 in the Pecten group compared to the Chlamys one might lead to overall lower $\mathrm{Cd}, \mathrm{Cu}$ and $288 \mathrm{Zn}$ concentrations in this organ. However, further studies in the Chlamys group are 289 needed to support this hypothesis.

\section{Geographical comparisons}

292 Scallops of different species within the same area and scallops of the same species from 293 different latitudes showed elevated variations in their ability to concentrate trace elements 294 (Table 5). Such variations are due to interspecific diversity but also to geographic 295 conditions. Accumulation of high metal concentrations, particularly $\mathrm{Cd}$, even in 296 unpolluted areas might be related to different bioavailability of the elements, to different 
297 feeding habits, as well as to physiological features. As regards to the concentrations

298 found in the gills, seawater appears to be an important source of metals for scallops.

299 However, trace element concentrations in the soft tissues and primarily in the digestive

300 gland might substantially be influenced by the metal content of their food. Indeed,

301 scallops are filter feeders using different types of food such as phytoplankton, detritus

302 and resuspended matter which are major components of the variation in food quality in

303 the field through variation in their carbon and nitrogen contents (Grant and Cranford,

304 1991, Alber and Valiela, 1996). It would therefore be of particular interest to characterise

305 the food composition and its metal concentrations of the different scallops.

306 As reported for other marine invertebrates (Cubadda et al., 2001), the use of scallops as

307 biomonitors on large geographical scales, i.e. between 44 to $46^{\circ} \mathrm{N}$ for the Bay of Biscay

308 and 61 to $63^{\circ} \mathrm{N}$ for the Faroe Islands, might be envisaged with caution. In this

309 investigation, the higher $\mathrm{Cd}$ concentrations found in A. opercularis from the Faroe

310 Islands compared to those from the Bay of Biscay highlighted that the contents of one or

311 more metals in marine organisms can be increased by specific geochemical or

312 hydrodynamic conditions. In the Faroe Islands, enrichment of metals due to industrial

313 contamination does not exist. Consequently, the high $\mathrm{Cd}$ concentrations in the tissues of

314 A. opercularis might be considered as natural in this sub-polar area. Reported $\mathrm{Cd}$

315 enrichment throughout the Arctic remained globally unclear. Several authors have

316 proposed that a phenomenon of $\mathrm{Cd}$ abnormality occurs in polar and subpolar areas,

317 leading to very high Cd concentrations in marine biota (Petri and Zauke, 1993, Bargagli

318 et al., 1996, Bustamante et al., 1998a, Zauke et al., 1999). Several results suggest that

319 such an abnormality has also to be considered in the Faroe Islands (Caurant et al., 1994, 

Bustamante et al., 1998b, 2004). Indeed, similarly to polar regions, soluble trace element concentrations in seawater appear to be relatively low around this area (Mart and Nürnberg, 1984). Despite that, very high Cd concentrations have also been found in several cephalopod species caught around the archipelago, i.e. from $2.1 \mu \mathrm{g} . \mathrm{g}^{-1} \mathrm{dwt}$ in the Loliginid squid Loligo forbesi, to $46.8 \mu \mathrm{g} \cdot \mathrm{g}^{-1} \mathrm{dwt}$ in the octopus Eledone cirrhosa (Bustamante, 1998, Bustamante et al., 1998b). Moreover, coastal invertebrates such as dog-whelks and limpets also displayed elevated Cd concentrations, i.e. $140 \mu \mathrm{g} \cdot \mathrm{g}^{-1} \mathrm{dwt}$ and $50 \mu \mathrm{g} \cdot \mathrm{g}^{-1} \mathrm{dwt}$, respectively (Dam, 2000). Therefore, the high Cd concentrations in the tissues of A. opercularis might reflect a global enrichment by this metal in the Faroe Islands biota. Nevertheless, the reasons of such an enrichment remain to be determined. In contrast, $\mathrm{Cu}$ and $\mathrm{Zn}$ appeared to be concentrated in much lower extent in the scallops from the Faroe Islands compared to those from the Bay of Biscay and from the English Channel (Bryan, 1973). Lower concentrations of these essential elements could be due to low bioavailability of these two metal in the Faroe Island waters. High Cd concentrations associated with low $\mathrm{Cu}$ and $\mathrm{Zn}$ values are typically attributed to the substitution of $\mathrm{Cd}$ ions for essential metals under deficient conditions (Zauke and Petri, 1993, Bustamante et al., 1998a). This possibly occurred in A. opercularis from the Faroe Islands. Indeed, the digestive gland showed a high $\mathrm{Cd} / \mathrm{Cu}$ ratio (i.e. 8.8) compared to the Bay of Biscay (i.e. 0.6). In the Faroe scallops, this high ratio was due to both elevated Cd concentrations and to low $\mathrm{Cu}$ concentrations. $\mathrm{Cu}$ concentrations in the digestive gland were lower than concentrations found in the temperate scallop species but in the same range than the concentrations reported for the Antarctic scallop A. colbecki (Table 5). Large amounts of $\mathrm{Cu}$ are essential to marine mollusks, for which $\mathrm{Cd}$ and $\mathrm{Cu}$ are known to interfere on the 
same type of metalloproteins (i.e. metallothioneins) in the digestive gland. A competition or a substitution between the two elements may have occurred in the Faroe scallops.

\section{CONCLUSION}

The three different species examined in this study accumulated high trace element concentrations in their tissues, particularly in the digestive gland and in the kidney. The accumulation of $\mathrm{Cd}$ was even higher for $\mathrm{Cd}$ in the subpolar Faroe area. In contrast to $\mathrm{Cd}$, lower $\mathrm{Cu}$ and $\mathrm{Zn}$ concentrations suggests a poor bioavailability of these essential elements in that area. Regardless of the species and the origin, Cd appeared to be associated to cytosolic proteins involved in detoxification functions. The presence of $\mathrm{Cu}$ and $\mathrm{Zn}$ on organites and membranes might be due to their essentiality.

\section{ACKNOWLEDGEMENTS}

We thank the 'Fiskirannsoknarstovan' (Torshavn, Faroe Islands) and IFREMER (Direction des Ressources Halieutiques, Nantes) for facilitating collections of the scallops on the RVs Magnus Heinasson and Gwen-Drez. This work was financially supported by the "Conseil Régional Poitou-Charentes" and Rhodia. We are grateful to the anonymous referees of this manuscript for their fruitful criticism.

\section{REFERENCES}


Alber, M., Valiela, I., 1996. Utilization of microbial organic aggregates by bay scallops, Argopecten irradians (Lamarck). J. Exp. Mar.Biol. Ecol. 195, 71-89.

Ballan-Dufrançais, C., Jeantet, A.Y., Feghali, C., Halpern, S., 1985. Physiological features of heavy metal storage in bivalve digestive cells and amoebocytes : EPMA and factor analysis of correspondences. Bio. Cell. 53, 283-292.

Bargagli, R., Nelli, L., Ancora, S., Focardi, S., 1996. Elevated cadmium accumulation in marine organisms from Terra Nova Bay (Antarctica). Polar Biol. 16, 513-520.

Berkman, P.A., Nigro, M., 1992. Trace metal concentrations in scallops around Antartica: extending the Mussel Watch Programme to the Southern Ocean. Mar. Pollut. Bull. 24 (6), 322-323.

Bryan, G.W., 1973. The occurrence and seasonal variation of trace metals in the scallops Pecten maximus (L.) and Chlamys opercularis (L.). J. Mar. Biol. Assoc. U.K. 53, 145166.

Bryan, G.W., 1976. Some aspects of heavy metal tolerance in aquatic organisms. In : Lockwood APM (ed) Effects of pollutants on aquatic organisms. Academic Press, London, p 7-34

Bustamante, P., 1998. Etude des processus de bioaccumulation et de détoxication d'éléments traces (métaux lourds et terres rares) chez les mollusques céphalopodes et bivalves pectinidés. Implication de leur biodisponibilité pour le transfert vers les prédateurs. $\mathrm{PhD}$ thesis, University of La Rochelle, France

Bustamante, P., Chérel, Y., Caurant, F., Miramand, P. 1998a. Cadmium, copper and zinc in octopuses from Kerguelen Islands, Southern Indian Ocean. Polar Biol. 19, 264-271. 
Bustamante, P., Caurant, F., Fowler, S.W., Miramand, P. 1998b. Cephalopods as a vector for the transfer of cadmium to top marine predators in the north-east Atlantic Ocean. Sci Total Environ.. 220, 71-80.

Bustamante, P., Germain, P., Leclerc, G., Miramand, P., 2002a. Concentration and distribution of ${ }^{210} \mathrm{Po}$ in the tissues of the scallop Chlamys varia and the mussel Mytilus edulis from the coasts of Charente-Maritime (France). Mar. Pollut. Bull. 44(10), 9971002.

Bustamante, P., Cosson, R.P., Gallien, I., Caurant, F., Miramand, P., 2002b. Cadmium detoxification processes in the digestive gland of cephalopods in relation to accumulated cadmium concentrations. Mar. Environ. Res. 53, 227-241.

Bustamante, P., Morales, F., Mikkelsen, B., Dam, M., Caurant, F., 2004. Individual and population significance of trace elements bioaccumulation in the grey seal Halichoerus grypus from the Faroe Islands. Mar. Ecol. Prog. Ser. 267, 291-301.

Caurant, F., Amiard, J.C., Amiard-Triquet, C., Sauriau, P.G., 1994. Ecological and biological factors controlling the concentrations of trace elements ( $\mathrm{As}, \mathrm{Cd}, \mathrm{Cu}, \mathrm{Hg}, \mathrm{Se}$, $\mathrm{Zn}$ ) in delphinids Globicephala melas from the North Atlantic Ocean. Mar. Ecol. Prog. Ser. 103, 207-219.

Cubadda, F., Conti, M.E., Campanella, L. 2001. Size-dependent concentrations of trace metals in four Mediterranean gastropods. Chemosphere 45, 561-569.

Dam, M., 2000. Integrated ecological monitoring in the coastal zone; Environmental Pollutants. The Food and Environmental Agency of the Faroe Islands, Report no. 2, 97p

Evtushenko, Z.S., Belcheva, N.N., Lukyanova, O.N., 1986. Cadmium accumulation in organs of the scallop Mizuhopecten yessoensis. II. Subcellular distribution of metals and metal-binding proteins. Comp. Biochem. Physiol. 83C, 377-383. 
428 Evtushenko, Z.S., Lukyanova, O.N., Belcheva, N.N., 1990. Cadmium bioaccumulation in organs of the scallop Mizuhopecten yessoensis. Mar. Biol. 104, 247-250.

Fowler, B.A., Gould, E., 1988. Ultrastructural and biochemical studies of intracellular metal-binding patterns in kidney tubule cells of the scallop Placopecten magellanicus following prolonged exposure to cadmium or copper. Mar. Biol. 97, 207-216.

George, S.G., 1980. Correlation of metal accumulation in mussels with the mechanisms of uptake, metabolism and detoxification: biochemical and ultrastructural studies. Thalassia jugoslav. 16, 347-365.

George, S.G., Pirie, B.J.S., Coombs, T.L., 1980. Isolation and elemental analysis of metal-rich granules from the kidney of the scallop, Pecten maximus (L.). J. Exp. Mar. Biol. Ecol. 42, 143-156.

Grant, J., Cranford, P.J., 1991. Carbon and nitrogen scope for growth as a function of diet in the sea scallop Placopecten magellanicus. J. Mar. Biol. Assoc. U.K. 71, 437-450.

450 Lukyanova, O.N., Evtushenko, Z.S., 1989. Binding of zinc and cadmium with 451 cytoplasmic proteins in the Yezo scallop at the increased concentrations of zinc in water. 452 Sov. J. Mar. Biol. 15, 306-311.

454 Mart, L., Nürnberg, H.W., 1984. Trace metal levels in the eastern Arctic Ocean. Sci. 
457 Mauri, M., Orlando, E., Nigro, M., Regoli, F. 1990. Heavy metals in the Antarctic scallop 458 Adamussium colbecki. Mar. Ecol. Prog. Ser. 67, 27-33.

Petri, G., Zauke, G.P., 1993. Trace metal in the crustaceans in the Antarctic Ocean.

Quéro, J.C., Vayne, J.J., 1998. Les fruits de mer et plantes marines des pêches françaises.

Delachaux \& Nestlé, Lausanne-Paris, 256 p.

Stone, H.C., Wilson, S.B., Overnell, J., 1986. Cadmium binding components of scallop (Pecten maximus) digestive gland. Partial purification and characterisation. Comp. Biochem. Physiol. 85 C, 259-268.

Uthe, J.F., Chou, C.L., 1987. Cadmium in sea scallop (Placopecten magellanicus) tissues from clean and contaminated areas. Can. J. Fish. Aquat. Sci. 44, 91-98.

Viarengo, A., Canesi, L., Mazzucotelli, A., Ponzano, E. 1993. Cu, Zn and Cd content in different tissues of the Antarctic scallop Adamussium colbecki : role of the metallothionein in heavy metal homeostasis and detoxification. Marine Ecology Progress

$480 \quad$ Series $95,163-168$.

481

Zar JH (1996) Biostatistical Analysis, $3^{\text {rd }}$ ed. Prentice-Hall, Upper Saddle River, NJ

484 Zauke, G.P., Savinov, V.M., Ritterhoff, J., Savinova, T. 1999. Heavy metals in fish from the Barents Sea (summer 1994). Sci. Total Environ. 227, 161-173. 
486 Table 1. Comparison of trace elements concentrations ( $\mu \mathrm{g} \cdot \mathrm{g}^{-1}$ dry wt) of dogfish liver 487 DOLT-2 (NRCC), and dogfish muscle (NRCC) determined in the present study with 488 certified values.

489

\begin{tabular}{|lcccc|}
\hline Metals & \multicolumn{2}{c}{ DOLT-2 $(\mathrm{n}=5)$} & \multicolumn{2}{c|}{ DORM-2 $(\mathrm{n}=5)$} \\
& Certified values & Present study & Certified values & Present study \\
\hline $\mathrm{Cd}$ & $20.8 \pm 0.5$ & $19.7 \pm 0.6$ & $0.043 \pm 0.008$ & $0.042 \pm 0.014$ \\
$\mathrm{Cu}$ & $25.8 \pm 1.1$ & $24.9 \pm 1.2$ & $2.34 \pm 0.16$ & $2.30 \pm 0.22$ \\
$\mathrm{Zn}$ & $85.8 \pm 2.5$ & $84.5 \pm 2.8$ & $25.6 \pm 2.3$ & $26.3 \pm 1.8$ \\
\hline
\end{tabular}

490

491 
492 Table 2. Mean $\pm \mathrm{SD}$ of $\mathrm{Cd}, \mathrm{Cu}$, and $\mathrm{Zn}$ concentrations $\left(\mu \mathrm{g} \cdot \mathrm{g}^{-1} \mathrm{dwt}\right)$ in the organs and tissues of three scallop species from the Bay of

493 Biscay and the Faroe Islands. N : number of pools (sum of the individuals)

\begin{tabular}{|c|c|c|c|c|c|c|c|c|}
\hline $\begin{array}{l}\text { Element } \\
\text { Species }\end{array}$ & Location & $\begin{array}{l}\text { Digestive } \\
\text { gland }\end{array}$ & Kidneys & Gonad & Gills & Muscle & $\begin{array}{l}\text { Remaining } \\
\text { tissues }\end{array}$ & $\begin{array}{c}\text { Whole soft } \\
\text { parts }\end{array}$ \\
\hline \multicolumn{9}{|l|}{$\mathrm{Cd}$} \\
\hline \multirow{2}{*}{$\begin{array}{c}\text { Aequipecten } \\
{ }^{-}\end{array}$} & Bay of Biscay & $27.5 \pm 4.24$ & $21.1 \pm 3.15$ & $3.99 \pm 3.17$ & $7.41 \pm 0.03$ & $0.70 \pm 0.24$ & $4.74 \pm 2.13$ & $5.70 \pm 1.21$ \\
\hline & Faroe Islands & $123 \pm 14$ & $159 \pm 80$ & $3.54 \pm 0.89$ & $8.46 \pm 3.38$ & $0.49 \pm 0.09$ & $10.5 \pm 2.84$ & $38.7 \pm 11.1$ \\
\hline Chlamys varia & Bay of Biscay & $40.0 \pm 4.43$ & $38.8 \pm 11.1$ & $2.11 \pm 0.27$ & $4.12 \pm 0.39$ & $0.54 \pm 0.08$ & $2.06 \pm 0.32$ & $7.69 \pm 0.77$ \\
\hline Pecten maximus & " & $264 \pm 33$ & $70.6 \pm 12.6$ & $5.28 \pm 5.44$ & $4.68 \pm 2.26$ & $2.01 \pm 1.07$ & $3.58 \pm 0.60$ & $29.7 \pm 12.0$ \\
\hline \multicolumn{9}{|l|}{$\mathrm{Cu}$} \\
\hline \multirow{2}{*}{$\begin{array}{c}\text { Aequipecten } \\
\text { "- }\end{array}$} & Bay of Biscay & $43.6 \pm 19.5$ & $507 \pm 144$ & $8.1 \pm 0.6$ & $7.1 \pm 0.7$ & $1.7 \pm 0.9$ & $4.5 \pm 0.8$ & $15.0 \pm 4.6$ \\
\hline & Faroe Islands & $14.0 \pm 0.8$ & $106 \pm 49$ & $6.5 \pm 0.7$ & $4.7 \pm 0.2$ & $1.0 \pm 0.1$ & $2.5 \pm 0.1$ & $7.6 \pm 2.3$ \\
\hline Chlamys varia & Bay of Biscay & $88.1 \pm 13.8$ & $142 \pm 20$ & $29.6 \pm 6.0$ & $8.1 \pm 0.8$ & $1.8 \pm 0.2$ & $5.5 \pm 0.4$ & $19.2 \pm 1.7$ \\
\hline Pecten maximus & " & $40.7 \pm 7.8$ & $13.5 \pm 2.0$ & $19.7 \pm 16.1$ & $5.3 \pm 2.4$ & $1.2 \pm 0.3$ & $3.4 \pm 0.3$ & $6.5 \pm 1.6$ \\
\hline \multicolumn{9}{|l|}{$\mathrm{Zn}$} \\
\hline \multirow{2}{*}{$\begin{array}{c}\text { Aequipecten } \\
\text { " }\end{array}$} & Bay of Biscay & $198 \pm 47$ & $31053 \pm 8147$ & $195 \pm 16$ & $384 \pm 74$ & $79 \pm 17$ & $200 \pm 35$ & $437 \pm 159$ \\
\hline & Faroe Islands & $77 \pm 14$ & $6632 \pm 3664$ & $120 \pm 15$ & $96 \pm 7$ & $39 \pm 4$ & $105 \pm 32$ & $193 \pm 106$ \\
\hline Chlamys varia & Bay of Biscay & $149 \pm 27$ & $24107 \pm 3465$ & $239 \pm 45$ & $232 \pm 99$ & $101 \pm 13$ & $181 \pm 61$ & $781 \pm 120$ \\
\hline Pecten maximus & " & $804 \pm 92$ & $7278 \pm 3041$ & $254 \pm 105$ & $143 \pm 4$ & $64 \pm 7$ & $87 \pm 6$ & $235 \pm 110$ \\
\hline
\end{tabular}


Table 3. Body distribution of $\mathrm{Cd}, \mathrm{Cu}$, and $\mathrm{Zn}(\%$ of the wet weight) in the organs and tissues of three scallop species from the Bay of

Biscay and the Faroe Islands. $\mathrm{N}$ : number of pools (sum of the individuals)

\begin{tabular}{|c|c|c|c|c|c|c|c|}
\hline Species & Location & $\begin{array}{l}\text { Digestive } \\
\text { gland }\end{array}$ & Kidneys & Gonad & Gills & Muscle & $\begin{array}{c}\text { Remaining } \\
\text { tissues }\end{array}$ \\
\hline \multicolumn{8}{|l|}{$\mathrm{Cd}$} \\
\hline Aequipecten & Bay of Biscay & $75 \pm 8$ & $4 \pm 3$ & $5 \pm 2$ & $3 \pm 1$ & $8 \pm 3$ & $12 \pm 2$ \\
\hline " & Faroe Islands & $90 \pm 3$ & $5 \pm 3$ & $1 \pm 0$ & $1 \pm 0$ & $<1$ & $3 \pm 1$ \\
\hline Chlamys varia & Bay of Biscay & $80 \pm 3$ & $8 \pm 2$ & $<1$ & $2 \pm 0$ & $4 \pm 1$ & $5 \pm 1$ \\
\hline Pecten maximus & " & $93 \pm 1$ & $2 \pm 1$ & $<1$ & $<1$ & $3 \pm 1$ & $1 \pm 0$ \\
\hline \multicolumn{8}{|l|}{$\mathrm{Cu}$} \\
\hline Aequipecten & Bay of Biscay & $52 \pm 9$ & $37 \pm 6$ & $5 \pm 3$ & $1 \pm 1$ & $8 \pm 5$ & $3 \pm 1$ \\
\hline " & Faroe Islands & $61 \pm 4$ & $18 \pm 10$ & $7 \pm 3$ & $4 \pm 1$ & $5 \pm 2$ & $5 \pm 2$ \\
\hline Chlamys varia & Bay of Biscay & $74 \pm 7$ & $12 \pm 3$ & $2 \pm 0$ & $1 \pm 0$ & $5 \pm 10$ & $6 \pm 1$ \\
\hline Pecten maximus & " & $70 \pm 6$ & $2 \pm 2$ & $11 \pm 8$ & $3 \pm 3$ & $11 \pm 3$ & $3 \pm 1$ \\
\hline \multicolumn{8}{|l|}{$\mathrm{Zn}$} \\
\hline Aequipecten & Bay of Biscay & $1 \pm 1$ & $97 \pm 1$ & $1 \pm 0$ & $1 \pm 0$ & $<1$ & $1 \pm 0$ \\
\hline " & Faroe Islands & $17 \pm 6$ & $53 \pm 18$ & $6 \pm 4$ & $5 \pm 2$ & $9 \pm 4$ & $9 \pm 5$ \\
\hline Chlamys varia & Bay of Biscay & $5 \pm 1$ & $72 \pm 4$ & $1 \pm 0$ & $2 \pm 1$ & $14 \pm 3$ & $7 \pm 2$ \\
\hline Pecten maximus & $"$ & $14 \pm 11$ & $81 \pm 14$ & $3 \pm 1$ & $1 \pm 0$ & $1 \pm 1$ & $1 \pm 0$ \\
\hline
\end{tabular}

498 
499 Table 4. Proportion of $\mathrm{Cd}, \mathrm{Cu}$, and $\mathrm{Zn}$ in the cytosol of the digestive gland cells (\% of the 500 wet weight) of three scallop species from the Bay of Biscay and the Faroe Islands. N : 501 number of individuals

\begin{tabular}{lccccc}
\hline Species & Location & $\mathrm{N}$ & $\mathrm{Cd}$ & $\mathrm{Cu}$ & $\mathrm{Zn}$ \\
\hline Pecten maximus & Bay of Biscay & 23 & $72 \pm 5$ & $43 \pm 4$ & $38 \pm 7$ \\
Chlamys varia & Bay of Biscay & 40 & $78 \pm 5$ & $25 \pm 8$ & $41 \pm 3$ \\
Aequipecten opercularis & Faroe Islands & 10 & $80 \pm 7$ & $35 \pm 16$ & $50 \pm 11$ \\
\hline
\end{tabular}

502 
503 Table 5. Mean $\pm \mathrm{SD}$ of $\mathrm{Cd}, \mathrm{Cu}$, and $\mathrm{Zn}$ concentrations $\left(\mu \mathrm{g} \cdot \mathrm{g}^{-1} \mathrm{dwt}\right)$ in different scallop

504 species from various locations. N: sample size.

\begin{tabular}{|c|c|c|c|c|c|c|}
\hline Species & Location & $\mathrm{N}$ & $\mathrm{Cd}$ & $\mathrm{Cu}$ & $\mathrm{Zn}$ & Reference \\
\hline \multicolumn{7}{|l|}{ Digestive gland } \\
\hline Amussium balloti & Australia & 10 & $111^{\mathrm{a}}$ & - & - & Francesconi et al. 1993 \\
\hline Adamussium colbecki & Antarctic & 30 & $142 \pm 57$ & $12.6 \pm 3.3$ & $74.9 \pm 25.4$ & Mauri et al. (1990) \\
\hline " & " & 6 & $26.51 \pm 6.09^{\mathrm{a}}$ & $3.52 \pm 0.49^{\mathrm{a}}$ & $17.42 \pm 2.91^{\mathrm{a}}$ & Viarengo et al. (1993) \\
\hline Aequipecten opercularis & Northeast Atlantic & 31 & $123 \pm 14$ & $14.0 \pm 0.8$ & $77 \pm 14$ & Present study \\
\hline$"$ & English Channel & 11 & 27 & $36.7 \pm 11.4$ & $132 \pm 26$ & Bryan (1973) \\
\hline$"$ & Bay of Biscay & 11 & $27.5 \pm 4.24$ & $43.6 \pm 19.5$ & $198 \pm 47$ & Present study \\
\hline Chlamys varia & $"$ & 41 & $40.0 \pm 4.43$ & $88.1 \pm 13.8$ & $149 \pm 27$ & $"$ \\
\hline Pecten jacobeus & Mediterranean Sea & 30 & $41.0 \pm 18.2$ & $16.6 \pm 6.6$ & $124 \pm 55$ & Mauri et al. (1990) \\
\hline$"$ & $"$ & 6 & $7.19 \pm 1.23^{\mathrm{a}}$ & $3.13 \pm 0.55^{\mathrm{a}}$ & $28.63 \pm 3.29^{\mathrm{a}}$ & Viarengo et al. (1993) \\
\hline P. maximus & English Channel & 11 & 321 & $57.9 \pm 27.4$ & $407 \pm 123$ & Bryan (1973) \\
\hline$"$ & Bay of Biscay & 11 & $264 \pm 33$ & $40.7 \pm 7.8$ & $804 \pm 92$ & Present study \\
\hline Placopecten magellanicus & Northwest Atlantic & 6 & $94.68 \pm 8.42^{\mathrm{a}}$ & - & - & Uthe \& Chou (1987) \\
\hline \multicolumn{7}{|l|}{ Kidney } \\
\hline Adamussium colbecki & Antarctic & 30 & $11.6 \pm 3.3$ & $4.0 \pm 1.7$ & $199 \pm 89$ & Mauri et al. (1990) \\
\hline Aequipecten opercularis & Northeast Atlantic & 31 & $159 \pm 80$ & $106 \pm 49$ & $6632 \pm 3664$ & Present study \\
\hline " & English Channel & 11 & 41 & $1285 \pm 591$ & $40800 \pm 7290$ & Bryan (1973) \\
\hline$"$ & Bay of Biscay & 11 & $21.1 \pm 3.15$ & $507 \pm 144$ & $31053 \pm 8147$ & Present study \\
\hline Chlamys varia & " & 41 & $38.8 \pm 11.1$ & $142 \pm 20$ & $24107 \pm 3465$ & " \\
\hline Pecten jacobeus & Mediterranean Sea & 30 & $10.7 \pm 4.0$ & $17.5 \pm 10.9$ & $2790 \pm 1340$ & Mauri et al. (1990) \\
\hline P. maximus & English Channel & 11 & 79 & $20.8 \pm 10.3$ & $19300 \pm 4800$ & Bryan (1973) \\
\hline$"$ & Bay of Biscay & 11 & $70.6 \pm 12.7$ & $13.5 \pm 2.0$ & $7278 \pm 3041$ & Present study \\
\hline Placopecten magellanicus & Northwest Atlantic & 6 & $62.61 \pm 25.33^{\mathrm{a}}$ & - & - & Uthe \& Chou (1987) \\
\hline
\end{tabular}

506

$507{ }^{\mathrm{a}}$ :values expressed relatively to wet weight. 